\title{
Obstacles of Success of Technology Parks: The Case of Jordan
}

\author{
Radwan Kharabsheh (Corresponding author) \\ Head, Department of Business Administration, Faculty of Economics and Administration Studies \\ The Hashemite University, Zarqa, Jordan \\ PO Box 1181, Swelleh, Postal Code 11910 Jordan \\ Tel.: 05-390-3333, Fax: 05-382-6613Ｅ-mail: r.kharab@hu.edu.jo
}

\author{
Ihab Khaled Magableh \\ Assisstant Proffesor, Head, Demarment of Managment Sciences \\ School of Management and Logestics Sciences, German Jordanian University \\ P.O. Box 35247 Amman 11180 Jordan, 00962777309308 \\ E-mail: Ihabmagableh@yahoo.co.uk / Ihab.magableh@gju.edu.jo \\ Talah S. Arabiyat \\ Dean, School of Management and Logistics Sciences \\ School of Management and Logestics Sciences, German Jordanian University \\ P.O. Box 35247 Amman 11180 Jordan \\ E-mail: talah.arabiyat@gju.edu.jo
}

Received: May 24, 2011

Accepted: July 25, 2011

Published: November 1, 2011

doi:10.5539/ijef.v3n6p219

URL: http://dx.doi.org/10.5539/ ijef.v3n6p219

\begin{abstract}
Numerous researchers argued that the goal of many technology parks and the factors driving innovation success are still a mystery. In addition, it is argued that the problem with analyzing technology parks and cluster building is that recent studies analyze "the most celebrated case studies... to 'explain' their success" and ignore the less successful ones especially in developing countries. This study uses intensive interviewing to explore obstacles to success of technology parks in Jordan. It identified the following obstacles: 1. absence of a culture of entrepreneurism, 2. lack of autonomy and independence from university officials and government bureaucrats, 3 . lack of a critical mass of companies that allows for synergies within parks and, 4. lack of a shared vision among parks' stakeholders. The study also found that the education system is unable to instill a culture of entrepreneurism among graduates therefore reducing the number of entrepreneurs and start-ups in Jordan.
\end{abstract}

Keywords: Technology parks, Innovation, Sustainable development, Entrepreneurism, Education system

\section{Introduction}

Technology parks provide a mechanism to promote and stimulate commercial and industrial innovation, encourage re-industrialization and ensure sustainable regional development. The UNESCO defines Science and Technology Parks (STPs) as "economic and technological development complexes that aim at fostering knowledge-based economies by bringing together scientific research, business and governmental organizations in one physical location, and supporting interrelationships between these groups." In addition to providing space for knowledge-based products, STPs can house centers for scientific research, technological innovation and incubation, training, forecasting, as well as facilities for fairs, exhibitions and market development. They are formally linked (and usually physically close) to centers of technological excellence, universities and/or research centers.

In a technology park knowledge can be diffused through formal and informal interpersonal or employee-related contacts amongst the firms (which may result from direct face-to-face interaction or more indirectly from the research ambience generated by, for example, a nearby leading firm), or knowledge may be dispersed through relationships with local universities or other institutions of higher learning and/or research (Wolfe and Gertler 2003). 
Indeed universities and colleges often play the role of an "anchor" and are a catalyst to high-technology company spinoffs (Berry 1998).

However, technology parks and incubation programs are not always successful (Sun, Ni and Leung 2007). For example, Colombo and Delmastro (2002) pointed out that "in spite of the diffusion of STPs in Europe, whether they have been successful or not in supporting new technology-based firms still is unclear". Some even concluded that technology parks in specific context might be a "technology fantasy" (Bakouros, Mardas, and Varsakelis 2002). In addition, it is argued that the problem with analyzing technology parks and cluster building is that recent studies analyze "the most celebrated case studies... to 'explain' their success" (Holbrook and Wolfe 2002).

Researchers, industry experts, and politicians increasingly highlight the role that small and medium enterprises (SMEs) play in creating income and employment (Akçomak 2009). Further, many politicians believe and economists have the intuition that new possibilities for growth, innovation, and job creation will come from new ventures (Wennekers and Thurik 1999). However, SMEs and new ventures face numerous challenges: they cannot benefit from economies of scale, have difficulties in gaining access to tangible and intangible resources, have limited access to scientific knowledge, and have poor management skills (Akçomak 2009). Therefore, it is agreed among policy makers and scholars that these SMEs deserve some type of nursery at their inception so as to protect them from violent competition with large business enterprises (Buratti, and Penco 2001).

An STP is one of the perceived effective ways to accelerate the growth and development of these SMEs (Aernoudt 2004). This is especially true in developing countries where the creation of national systems of innovation represents a paradigm shift in "growth theories" (Porter, 1990). Numerous researchers linked STPs to regional development and innovation. For example, Kelessidis (1998) found that STPs played a significant role in regional development and innovation through providing firms with services such as information dissemination, technology brokerage, partner searching, and linking industry to research. Koskela and Järvelin (2004) found that STPs assisted local firms and therefore regional development in two ways: first, local firms and new start-ups used STPs to find financers, suppliers and customer and, secondly, STPs assisted firms by intermediating firms' relationships with innovation based partners like universities and research institutions.

Akçomak (2009) reviewed the literature on incubators in developed and developing countries. He noted that contemporary successful incubators are profit-oriented, provide a wide range of services, focus more on intangible business services, and employ qualified managers and support staff. He argued that STPs reflect the institutional set-up, creativity, and policy innovativeness in a society. Therefore, he argued, the policy on STPs should be well-integrated with other policies for entrepreneurship promotion and economic development, such as education and institutional deregulation. Perhaps the most striking examples are the development STPs in China and India. China's STPs began in the mid-eighties and contributed significantly to economic development; employing more than 5 million employees with more than 38,000 businesses nationally. Technopark Kerala, one of India first parks, hosted more than 125 companies, employed more than 17,000 professionals and accounts for $70 \%$ of Kerala's exports.

The case has not been so successful in the Middle East even with some of the shinning names like the Knowledge Oasis in Oman and Education City, Qatar. Even though the Middle East region is dominated by SMEs, more than $90 \%$ in almost all countries, which provides a great environment for the use of STPs, their use have been limited in size and scope and their effectiveness and success is questionable. Moreover, there is a dearth of studies on STPs in the Middle East. This paper uses intensive interviewing (Kvale 1996; Reinharz 1992) of six Jordanian STPs' mangers, managers, managers of tenant firms, deans of scientific research of the associated universities to explore the obstacles of success these parks.

\section{Success factors of STPs}

While there is a considerable amount of research on the performance of incubation programs (Mian 1996; 1997; Sherman 1999; Lindelof and Lofsten 2002; Siegel, Westhead, and Wright 2003; Bigliardi, et. al. 2005), few studies have examined obstacles to success especially in developing countries. The American National Business Incubation Association (NBIA) estimates that there are more than 1000 business incubators in North America, up from only 12 in 1980; and the number at present exceeds 4000 worldwide (Sun, Ni and Leung 2007). Numerous STPs are very successful in fostering growth of emerging entrepreneurs, creating new job opportunities, and speeding up development of regional economy (Lee and Yang 2000; Walcott 2003; Phan, Siegel and Wright 2005). Successful examples exist in Italy (Colombo and Delmastro 2002), China (Sutherland 2005; Lai, and Shyu 2005), Poland (Matusiak 2003), Singapore (Koh, Koh, and Tschang 2005), Korea (Lee 2003), Nigeria (Adegbite 2001), and Brazil (Lalkaka 2003), this is of course in addition to the North American and UK parks that have been world class 
exemplars in developing such incubation programmes to enhance the growth of regional economies and foster new firm development.

However, STPs are not always successful. Evidence on the effectiveness of STPs is not conclusive. For example, Colombo and Delmastro (2002) indicated that "in spite of the diffusion of STPs in Europe, whether they have been successful or not in supporting new technology-based firms still is unclear". Other researchers even argued that STPs in some context may be a "technology fantasy" (Bakouros, Mardas, and Varsakelis 2002). There is little systematic research and empirical study on the relationship between critical success factors and the performance of incubation program. Even more important is the obstacles to success of STPs especially in developing countries where STPs are relatively a new phenomena.

Numerous studies examined STPs' success from different perspectives. For example, Smilor and Gill (1986) identified ten critical success factors from the incubator perspective, and four from the tenant company perspective. Autto and Klofsten (1998) identified configuration parameters including proximity to major universities, or technology sites, availability of on-site manufacturing facilities, competent science park management, accessibility of venture capital funding, and prudent tenant selection criteria. Phan, Siegel and Wirhgt (2005) suggested that research should analyze at four levels; the incubator, the entrepreneur, and the system levels. Watkins-Mathys and Foster (2006) explored China's R\&D intensity and hi-tech policy and hi-tech companies' performance inside and outside STPs. They found among others that while entrepreneurship is very important for STPs success it was still underdeveloped in China and therefore was perceived as an obstacle to success.

\section{Methodology}

Data collection comprised semi structured intensive interviews and document analysis of both technology parks managers, business development managers and marketing managers and mangers of tenant firms in the technology parks. In total 30 interviews were conducted. The interviews were recorded and transcribed. The process of data collection and analysis proceeded iteratively in accordance to the interpretive research tradition (Walsham 2006). Thematic content analysis (Bardin 2007) was used to analyze the data collected during the interviews. While an interview is a direct conversation (Lofland and Loffland 1984; 1995); intensive interviewing permits an in-depth exploration of a particular topic or experience and thus, is a useful method for interpretive inquiry.

The in-depth nature of an interview fosters eliciting each participant's interpretation of his or her experience. The interviewer seeks to understand the topic and the interview participant has the relevant experiences to shed light on it (Fontana and Frey 1994; Seidman 1997). Therefore, the interviewer's questions ask the participant to describe and reflect upon his or her experiences in ways that seldom occur in everyday life.

\subsection{Data set}

Despite the presence of more than 20 public and private universities in Jordan the number of existing STPs in the country is 8 of which only four are associated with universities, one is associated to the Jordanian Armed Forces (JAF) and the remaining 3 are managed under government bodies. One problem faced by the researcher was the naming of the entities under study. With regards to the size of STPs; all STPs were small projects both in magnitude and scope. Surveyed projects generated from 100,000 Jordan Dinar (JD) to less than 1000,000 JD at max. (with the exception of the Science Park run by the armed forces). They were very specialized in the kind of firms they hosted (limited scope) depending on where the STP was initiated originally. Most STPs were initiated from within the engineering departments in order to provide students with training opportunities. Managers of STPs were engineers. There is a perception among academics that STPs and incubation programs are mere extensions of engineering departments therefore; depriving these entities from the input of economists, management experts and entrepreneurships. Indeed, there was confusion among incubation program managers who confused their limited incubation programs with the more independent, large scale STPs. At least two of the university entities were incubation programs in transition and not fully developed STPs. The STP attached JAF was excluded from this study since it was a very successful STP and operated to a world class standards. The informants of the study consisted of managers of parks, managers of tenant firms, university vice presidents, SMEs experts, deans of research at universities and government officials in the Ministry of Higher Education.

\section{Obstacles to Success}

The interviews revealed a variety of obstacles that reduced or inhibited the success of STPS in Jordan.

\subsection{Absence of a culture of entrepreneurism}

One of the major roles of a technology park is that of linking research, technology, capital and know-how to leverage entrepreneurial talent, accelerate the development of new technology-based firms, and speed up the commercialization of technology. It is therefore important to elaborate more on the concepts of entrepreneurship and 
commercialization. Watkins-Maythys and Foster (2006: p. 250) interpret entrepreneurship as being made up of two elements. The first is the "why, when, and how opportunities for the creation of goods and services come into existence" which incorporates scientific discoveries (or innovation) as a precursor to this process and the processes by which individuals pursue and exploit opportunities and the process by which new organizations come into existence. The second, comprises cognitive entrepreneurship which helps us "to understand how entrepreneurs think and "why" they do some of the things they do". The researchers also add entrepreneurial learning whereby the entrepreneur learns by doing - learns from his/her experience. Therefore, a culture of entrepreneurism means the ability of the entrepreneur to find opportunities and innovative solutions, exploit these opportunity and as a result the creation of startups and new ventures. This entails a trial and error approach that carries a great amount of risk within. And even when successful inventions come about; the challenge then becomes in commercializing these innovations. With regards to 'commercialization', Watkins-Maythys and Foster (2006: p. 250) define it as the ability of a firm or a private sector champion acquainted with market demand to translate innovative concepts into usable products or services through R\&D, manufacturing processes (where appropriate) and marketing processes. Both the trial and error approach and the ability to commercialize require university graduates, business managers and government bureaucrats to share these values and have the necessary skills.

While it has been long argued that the entrepreneurial function is a vital component in the process of economic growth (Jennings 1994), this must be reflected in the role that universities need to play in rehabilitation and training of human resources; then in moving towards creativity and innovation through a well-defined, flexible, dynamically changeable methodology that meets the needs of the employment market and its future developments.

However, the situation in the Arab world and in Jordan is different. Results from the interviews showed that the majority of university graduates who enter the workforce do not possess the necessary skills for effective and rewarding participation. Participants agreed that university graduates in Jordan have a good knowledge base but it is unfocused, unlinked, unstable, and sometimes not modern depriving them from the necessary and needed entrepreneurial skills. Participants argued that the delivery of higher education in Jordan has so far been poor in terms of quality and relevance. In addition, even though the number of universities has increased in the last few decades, which results in a higher number of graduates, unemployment is still high, reaching up to 12.3 percent in 2009 (DOS 2009). Similarly, the number of patents registered in Jordan is still very low. Even with an increase in the number of registered innovations, number of scientific journals, funded research, use of computers and communications capabilities, the number of patents registered in Jordan has not grown by the same percentage. For example, the number of registered patents for the 2005, 2006 and 2007 were 4, 6, and 9 respectively which is very low compared to 41 in Egypt and 31 in Saudi for the year 2007 (WIPO, 2009).

With regards to the role of universities, there exists confusion amongst Jordanian universities regarding their role in the knowledge-based economy. The overall educational institutions' approach emphasizes traditional teaching and research whereas the concept of commercialization is not in the least incorporated in the mission statements of many Jordanian universities, thereby impeding the execution of joint research projects with the industry. The result is a curriculum that does not advocate a trial and error approach or the use of more open and modern teaching approaches such as: use of case studies and projects, addition of subjects on SMEs, entrepreneurship, project management and feasibility studies, and most importantly the provision of internships for students.

In addition there is a mismatch between output and labor market. Participants argued that a high percentage of graduates are working in fields that do not correspond to their education and specialties. One SMEs expert contended:

The major complaints of the companies center on the weaknesses of university graduates in the areas of communication, creativity, innovation, and scientific levels. I believe that the solution to this problem comes from changing the educational system. We need a good modern education system that can provide graduates with tools to acquire knowledge, develop technical and managerial skills, enhance innovation and creativity (entrepreneurship), develop concepts, promote capabilities, develop personality, and build experience.

This mismatch problem is both a cause and an effect of the lack of institutional relationships between industry and academia in the country. One academic argued:

The lack of meaningful links between academia and those companies that can benefit from its output of students in the employment market is a recognizable problem. These links are either weak or do not exist. Such links could play a vital role in promoting workforce development, imparting practical learning, and ensuring that educational system graduates can be employed effectively upon graduation. Promoting links between educational institutions and the workplace can provide an employer with input efficiently into educational planning, and allow students to observe and experience the "real" working world. 
Therefore, establishing a relationship with the production sectors can help in identifying the suitability of educational programs, curriculum, specialties, methods, and training for the labor market and its future needs. Several academics and educational planners stress the need for restructuring, reorganization and reevaluation of the educational system (Khasawneh 2001; Khaldi 1993). Strategies should enhance the implementing of more rigorous academic standards, developing evaluation systems for the quality of graduates, and for modernizing and reforming the curriculum. Also, new strategies should include: encouraging innovative academic delivery systems, encouraging research partnerships between universities and the private sector in order to identify the market needs and then map them onto the educational system, and introducing career guidance in the educational system.

Finally, the role of the financial system plays a major role in the success of commercializing new innovations. Therefore, the availability and ease of acquisition of funds to startups and new ventures is crucial to the success of STPs. Jordan spends less than $0.36 \%$ of GDP on R\&D which is one third of developing countries rate of $1 \%$ of GDP. It also has a weak financial system that is reserved, risk averse and has strict rules for the provision of funding (DOS, 2009). One SME expert comments:

There is very little money in Jordanian universities for funding basic and secondary research activities and even less money for supporting startups. Unless there is a major change in this policy the number of entrepreneurs will not increase. An option would be to open up Jordan to foreign direct investment (FDI) as a substitute for local funding. FDI presents graduates with the necessary entrepreneurial skills and possible funding for startups.

\subsection{A lack of autonomy from university officials and government bureaucrats}

In order to create a risk taking environment where participants have the freedom to try and fail; managers agreed that technology parks' management should be independent from both the university and government bureaucrats. One manger commented:

We are treated just like any other department in the faculty. I have no autonomy whatsoever. Even the income we generate goes directly to finance! I have three layers of management between me and the vice president of the university which makes communication almost impossible without some kind of filtering.

Another manager/researcher argued that:

At the technology park level, universities and government bureaucrats do not usually have the capability to assess risks and potential benefits of financing startups and the creation of technology-based enterprises. They don't have the skills and when they have it they don't want to take any risk.

More importantly universities treat technology parks as mere real estate projects ignoring their potential benefits and focusing too much on cost and review management. A technology park manager argued:

I don't think that the vice president [in this case the decision maker] really understands what a technology park is all about. For the university it is just a way to generate a supplementary income. The training that students get is a bonus!

\subsection{Lack of a critical mass of companies that allows for synergies within the STP}

Participants agreed that an enabling environment in which the technology park operates can be detrimental to its success. According to the participants there are numerous enablers to the success of a technology park which may include: the presence of knowledge workers and skilled labor in the immediate environment of the technology park, the availability of the right communication energy and real estate infrastructure, the availability of IP offices within the technology parks. While these may be available for the parks under study the biggest problem seems to be in the number of companies and startups that participate in the park. Most of the technologically based firms in Jordan are based in the capital Amman where commercial activity is focused in Jordan. For parks outside the capital attracting firms is a big challenge.

One manager commented:

Our park revolves around the activity of three major software development firms. It was a big thing that we succeeded in attracting them to the North because they wish to stay close to Amman where the business is and where most of their clients are based. It is much more difficult with smaller firms and those who are not in the software development.

Participants agreed that size matters. The greater the number of participating firms in the park the more synergy is likely to result and the more successful the parks are. One manager commented:

Indeed the bigger the size the more synergy can be produced. Having the right size is the biggest challenge. At the moment it is the biggest obstacle. 


\subsection{Lack of a shared vision among the technology park stakeholders.}

Due to the nature of STPs and the fact that numerous parties are involved in its creation and development; it is important that these parties have an agreement and understanding of what STPs should do both in the short and long run. The aim is to link the strategies of the universities and the tenant firms with associated government bodies and the national agenda in the country. However, before this can be achieved there is a need to review university strategies to examine how these universities perceive their purpose. Research is not seen is a major goal of universities in Jordan. There is a problem both in the quality and quantity of the research produced. First, Jordan spends less than $0.36 \%$ of its GDP on R\&D. Further, researchers in academia are driven by promotion and conduct research for the sole purpose of prompting and not based on the needs of local community and the country therefore compromising the quality of research. With regards to the educational system a comprehensive review is needed to instill a culture of entrepreneurship that starts at school but that is enhanced and supported at universities. At the same time there is a need for national agenda to set Jordan's R\&D priories that drives all the previously mentioned strategies.

One park manager argued:

To seek a shared vision among senior stakeholders of what success in [city name] would look like in 3 years time and to begin the process of developing a strategy to achieve that vision is crucial for the parks' success.

Another manager noted that:

There is a lack of senior stakeholders' involvement in generating the strategy. Therefore the differing and conflicting goals and motives of the different parties reduced the chances for success.

\section{Conclusions and discussion}

This study used intensive interviewing to explore obstacles to success of technology parks in Jordan. The study identified the following obstacles to success: 1 . absence of a culture of entrepreneurism, 2. lack of autonomy and independence from university officials and government bureaucrats, 3. lack of a critical mass of companies that allows for synergies within parks and finally, 4. lack of a shared vision among parks' stakeholders. The study also found that the major obstacle to success of STPs in Jordan is a missing culture of entrepreneurship that is caused by the failure of the education system to instill entrepreneurship and risk taking both at schools and universities. The overall educational institutions' approach emphasizes traditional teaching and research whereas the concept of commercialization is not in the least incorporated in the mission statements of many Jordanian universities, thereby impeding the execution of joint research projects with the industry. The result is a paucity of graduates with entrepreneurial and business skills, which may require Jordanian universities to consider introducing these skills into the curriculum. The situation is further complicated by the weak structure of the financial system in Jordan that makes it difficult for start ups to obtain funding to commercialize their innovations. Alternatively, opening up the Jordanian market further to the activities of multinationals through FDI may provide employment and/or business opportunities for Jordanian graduates where they can learn business and entrepreneurial skills. In addition, STPs' management should aim to build a consensus or at least an understanding among park stakeholders so that the benefits and values are maximized and all interests are served. Successful STP' management should make regular meeting and gatherings among tenants of the park, government officials, and community representatives to open communication channels. This process serves to build relationships at the grass root levels and helps the different stakeholders to reach a consensus on what STPs should do.

\section{References}

Adegbite, O. (2001). Business Incubators and Small Enterprise Development: The Nigerian Experience. Small Business Economics. 17:157-166. http://dx.doi.org/10.1023/A:1011801018398

Aernoudt, R. (2004). Incubators: Tool for Entrepreneurship? Small Business Economic. 23:127-135. http://dx.doi.org/10.1023/B:SBEJ.0000027665.54173.23

Akçomak, I. (2009). Incubators as Tools for Entrepreneurship Promotion in Developing Countries. UNU-MERIT Research Workshop on Entrepreneurship, Technological Innovation, and Development, Maastricht, Netherlands.

Autto, E., Klofsten, M. (1998). A Comparative Study of Two European Business Incubators. Journal of Small Business Management. 36(1):30-43.

Bakouros, Yiannis L., Mardas, Dimitri C. and Varsakelis, Nikos C. (2002). Science Park, a High Tech Fantasy? An Analysis of the Science Parks of Greece. Technovation, 22:123-128. http://dx.doi.org/10.1016/S0166-4972(00)00087-0

Bardin, L. (1977). An?lise de conte?do, PUF :Paris. 
Berry, M. (1998). Strategic Planning in Small High Tech Companies. Long Range Planning.31(3): 455-466. http://dx.doi.org/10.1016/S0024-6301(98)80012-5

Bigliardi, B., Dormio, A. I., Nosella, A. and Petroni, G. (2005). Assessing Science Parks' Performances: Directions from Selected Italian Case Studies. Technovation (In press).1-17.

Briggs, A. and Watt, S. (2001). Technology and Research Parks. Report in Impacts of National Information Technology Environments on Business, Washington, D.C.: American University.

Buratti, N. and Penco, L. (2001). Assisted Technology Transfer to SMEs: Lessons from an Exemplary Case. Technovation. 21(1):35-43. http://dx.doi.org/10.1016/S0166-4972(00)00015-8

Colombo, M. G. and Delmastro, M. (2002). How Effective are Technology Incubators? Evidence from Italy, Research Policy. 31(7):1103-1123. http://dx.doi.org/10.1016/S0048-7333(01)00178-0

Department of Statistics. (2009). Statistical Year Book. Department of Statistics. Amman. Jordan.

Drescher, D. (2001). Research Parks: A Brief Overview of Research Parks for Economic Developers", http://www.unc.edu/depts/dcrpweb/courses/261/drescher/index.html. visited December 14, 2008.

Fontana, A. and Frey, J. (1994). Interviewing: The Art of Science. In N. Denzin and Y. Lincoln (Eds.), Handbook of Qualitative Research (pp. 361-377), C.A.: Thousand Oaks.

Holbrook, A. and Wolfe, D. (2002). Knowledge, Clusters and Regional Innovation. Montreal and Kingston: McGill-Queen's.

Jennings, D. F. (1994). Multiple Perspectives of Entrepreneurship, South Western Publishing.

Kelessidis, V. (1998). The Role of Technology Parks in Regional Development - The Case of Northern Greece", XV IASP World Conference on Science \& Technology Parks, Perth, Western Australia, 18-23 October.

Khaldi, O. (1993). Science and Technology in Servicing Development”, Jordanian Scientific Week, 21-25 (August).

Khasawneh, S. (2001). University Education in Jordan, Reality and Desires. Abdul Hamid Shouman Establishment Forum, Amman, Jordan. Koh, Francis C. C., Koh, Winston T. H. and Tschang, Feichin T. (2005). An Analytical Framework for Science Parks and Technology Districts with an Application to Singapore, Journal of Business Venturing. 20:217-239. http://dx.doi.org/10.1016/j.jbusvent.2003.12.002

Koskela, H. and J?rvelin, A. (2004). The Role of Science Parks in Developing Company Networks, FRONTIERS OF E-BUSINESS RESEARCH, http://www.ebrc.fi/kuvat/507-519_04.pdf (May, 2010).

Kvale, S. (1996). Interviews: An Introduction to Qualitative Research Interviewing, C.A.:Thousand Oaks, Sage.

Lai, Hsien-Che and Shyu, Joseph Z. (2005). A Comparison of Innovation Capacity at Science Parks Across the Taiwan Strait: The Case of Zhangjiang High-Tech Park and Hsinchu Science-Based Industrial Park, Technovation. 25:805-813.

Lalkaka, R. (2001). Best Practices in Business Incubation: Lessons (yet to be) Learned. International Conference on Business Centers: Actors for Economic \& Social Development, Brussels, 14-15 November.

Lee, K. B. (2003). The Evolutionary Process of Venture Incubation in Korea, International Journal Entrepreneurship and Innovation Management. 3(1/2):78-86. http://dx.doi.org/10.1504/IJEIM.2003.002220

Lee, W. H. and Yang, W. T. (2000). The Cradle of Taiwan High Technology Industry Development-Hsinchu Science Park (HSP), Technovation. 20:55-59. http://dx.doi.org/10.1016/S0166-4972(99)00085-1

Lindelof, P. and Lofsten, H. (2002). Growth, Management and Financing of New Technology Based Firms-Assessing Value-Added Contributions of Firms Located on and off Science Parks, Omega. 30:143-154.

Lofland, J. and Lofland, L. (1995). Analyzing Social settings: A guide to qualitative observation and analysis, C.A.: Wadsworth, 3rd ed.

Lofland, J., Lofland, L. (1984). Analyzing Social Settings: A Guide to Qualitative Observation and Analysis, C.A.:Wadsworth.

Matusiak, K. B. (2003). Business Incubators in Poland. International Journal of Entrepreneurship and Innovation Management. 3(1/2):87-98. http://dx.doi.org/10.1504/IJEIM.2003.002221

Mian, Sarfraz A. (1996). Assessing Value-Added Contributions of University Technology Business Incubators to Tenant Firms, Research Policy. 25(3):325-335. http://dx.doi.org/10.1016/0048-7333(95)00828-4 
Mian, Sarfraz A. (1997). Assessing and Managing the University Technology Business Incubator: An Integrative Framework. Journal of Business Venturing. 12:251-285. http://dx.doi.org/10.1016/S0883-9026(96)00063-8

Phan, P. H., Siegel, Donald, S., and Wright, M. (2005). "Science Parks and Incubators: Observations, Synthesis and Future Research. Journal of Business Venturing. 20:165-182.

Porter, M. E. (1990). The Competitive Advantage of Nations, New York: Free Press.

Reinharz, S. (1992). Feminist Methods in Social Research, New York: Oxford University.

Seidman, S. (1997). Difference Troubles: Queering Social Theory and Sexual Politics, Cambridge: Cambridge University Press. http://dx.doi.org/10.1017/CBO9780511557910

Sherman, H. D. (1999). Assessing the Intervention Effectiveness of Business Incubation Programmes on New Business Start-ups. Journal of Developmental Entrepreneurship. 4(2):117-133.

Siegel, D. S., Westhead, P. and Wright, M. (2003). Assessing the Impact of University Science Parks on Research Productivity: Exploratory Firm-Level Evidence From the United Kingdom. International Journal of Industrial Organization. 21:1357-1369, http://dx.doi.org/10.1016/S0167-7187(03)00086-9

Smilor, R. W. and Gill, M. D. Jr. (1986). The New Business Incubator: Linking Talent, Technology, Capital, and Know-How, Massachusetts: Lexington.

Sun, H., Ni, W. and Leung, J. (2007). Critical Success Factors for Technological Incubation: Case Study of Hong Kong Science and Technology Parks. International Journal of Management. 24(2):346-363.

Sutherland, D. (2005). China's Science Parks: Production Bases or a Tool for Institutional Reform? Asia Pacific Business Review. 11(1):83-104. http://dx.doi.org/10.1080/1360238052000298399

Walcott, S. M. (2003). Chinese Science and Technology Industrial Parks, Hampshire: Ashgate Publishing.

Walsham, G. (2006). Doing Interpretive Research. European Journal of Information Systems. 15(3):320-330. http://dx.doi.org/10.1057/palgrave.ejis.3000589

Watkins-Mathys, L. and Foster, M. (2006). Entrepreneurship: The Missing Ingredient in China's STIPs? Entrepreneurship \& Regional Development. 18:249-274

Wennekers, S., and Thurik, A. (1999). Linking Entrepreneurship and Economic Growth. Small Business Economics. 13:27-55.

World Intellectual Property Organization. (2009). Statistical Publication. http://www.wipo.int/ipstats/en/statistics/patents/ (July, 2010).

Wolfe, D. and Gertler, M. (2003). Lessons from the ISRN Study of Cluster Development. In (Ed.) D. A. Wolfe, Clusters Old and New: The Transition to a Knowledge Economy in Canada's Regions (pp. 1-36). Kingston: School of Policy Studies, Queen's University and McGill-Queen's University Press. 